\title{
The $R$-Stereoisomer of Ketamine as an Alternative for Ketamine for Treatment-resistant Major Depression
}

\author{
Kenji Hashimoto \\ Division of Clinical Neuroscience, Chiba University Center for Forensic Mental Health, Chiba, Japan
}

\section{TO THE EDITOR}

The N-methyl-D-aspartate (NMDA) receptor antagonist ketamine is one of the most attractive antidepressants for treatment-resistant major depression. ${ }^{1,2)}$ I read the recent article by Murrough et al. ${ }^{3)}$ about the rapid and robust antidepressant effects of a single intravenous infusion of ketamine in treatment-resistant patients with major depression with great interest. In the two-site randomized controlled trial, they used the anesthetic benzodiazepine midazolam as a control drug to optimize their design and mitigate the effects of nonspecific factors on the antidepressant-related outcome. Analysis of the primary outcome measure showed that the ketamine group experienced greater improvement in terms of MontgomeryÅsberg depression rating scale (MADRS) scores than did the midazolam group. Furthermore, the response at 24 hours was also greater in the ketamine than in the midazolam group. Eight (17\%) of the 47 patients receiving ketamine experienced significant dissociative symptoms immediately after the ketamine infusion, although these symptoms resolved by 2 hours post-infusion. The relationship between dissociative symptoms and the antidepressant effects of ketamine was not reported. Other common adverse events were observed in both groups. Because of dissociative side effects of ketamine, it is necessary to identify treatment-resistant patients who should not receive ketamine. ${ }^{4)}$

Ketamine (or $R S( \pm)$-ketamine) is a racemic mixture containing equal parts of $R(-)$-ketamine and $S(+)$ ketamine. $S$-ketamine has an approximately fourfold greater affinity for NMDA receptors than does $R$-stereoisomer. ${ }^{5)}$ Furthermore, $S$-ketamine shows an approx-

Received: November 26, 2013 / Accepted: November 27, 2013

Address for correspondence: Kenii Hashimoto, PhD

Division of Clinical Neuroscience, Chiba University Center for

Forensic Mental Health, 1-8-1 Inohana, Chiba 260-8670, Japan

Tel: +81-423-226-2517, Fax: +81-423-226-2561

E-mail: hashimoto@faculty.chiba-u.jp imately three-to-fourfold greater anesthetic potency and is associated with more undesirable psychotomimetic side effects compared with $R$-stereoisomer. ${ }^{5)}$ Recently, we reported that $R$-ketamine showed greater potency and longer-lasting antidepressant effects than $\operatorname{did} S$-ketamine in a rodent model of depression. ${ }^{6}$

A positron emission tomography study in healthy volunteers demonstrated that psychotomimetic doses of $S$-ketamine markedly increased the cerebral metabolic rates of glucose (CMRglu). ${ }^{7)}$ In contrast, equimolar doses of $R$-ketamine tended to decrease CMRglu across the brain, producing no psychotic symptoms but, instead, a state of relaxation and well being. ${ }^{7)}$ Interestingly, at the doses tested, $R$-ketamine produced a state of relaxation and elation, which was correctly identified as a drug effect by all subjects, even though $R$-ketamine produced an only marginally significant change in mood scores. ${ }^{7)}$

Taken together, these data suggest that the $R$-stereoisomer of ketamine would be an alternative antidepressant for ketamine as $R$-ketamine may be free of psychotomimetic side effects.

\section{Acknowledgments}

Dr. Hashimoto is an inventor on a filed patent application on "The use of R-ketamine in the treatment of psychiatric diseases" by Chiba University. Dr. Hashimoto has served as a scientific consultant to Astellas and Taisho, and he also received the research support from Abbvie, Dainippon Sumitomo, Otsuka, and Taisho.

\section{REFERENCES}

1. Hashimoto K. Therapeutic implications for NMDA receptors in mood disorders. Expert Rev Neurother 2013;13:735-737.

2. Krystal JH, Sanacora G, Duman RS. Rapid-acting glutamatergic antidepressants: the path to ketamine and beyond. Biol Psychiatry 2013;73:1133-1141.

3. Murrough JW, Iosifescu DV, Chang LC, Al Jurdi RK, Green CE, Perez AM, et al. Antidepressant efficacy of ketamine in treatment-resistant major depression: a two-site

(c) This is an Open-Access article distributed under the terms of the Creative Commons Attribution Non-Commercial License (http://creativecommons.org/licenses/by-nc/3.0) which permits unrestricted non-commercial use, distribution, and reproduction in any medium, provided the original work is properly cited. 
randomized controlled trial. Am J Psychiatry 2013;170: 1134-1142.

4. Rush AJ. Ketamine for treatment-resistant depression: ready or not for clinical use? Am J Psychiatry 2013;170:10791081.

5. Domino EF. Taming the ketamine tiger. 1965. Anesthesiology 2010;113:678-684.

6. Zhang JC, Li SX, Hashimoto K. $R$ (-)-Ketamine shows greater potency and longer lasting antidepressant effects than S (+)-ketamine. Pharmacol Biochem Behav 2014;116: 137-141.

7. Vollenweider FX, Leenders KL, Oye I, Hell D, Angst J. Differential psychopathology and patterns of cerebral glucose utilisation produced by $(S)$ - and $(R)$-ketamine in healthy volunteers using positron emission tomography (PET). Eur Neuropsychopharmacol 1997;7:25-38. 